Ann. Génét. Sél. anim., 1975, 7 (4), 421-425.

\title{
HERITABILITY ESTIMATES OF HATCHING TIME IN THE FAYOUMI CHICKENS
}

\author{
F. H. ABDOU and H. AYOUB* \\ Animal Production Department, \\ Faculty of Agric., Shebin El-Kom, Tanta Univ. \\ * Faculty of Agric., Ain Shams Univ., \\ Cairo
}

\section{SUMMARY}

Pedigree Fayoumi eggs were collected from individual sire matings, and were used for heritability estimates of hatching time. The eggs were saved for a period of ten days before setting. It was noticed that the distribution of hatching time approached normality with a mean of $2 \mathrm{I}$ days plus 1.28 hours. Heritability estimates of hatching time were $h_{d}^{2}=0.28, h_{s}^{2}=0.08$ and $h_{d+s}^{2}=0.18$. The correlation between the time of egg storage and hatching time was highly significant (0.37). The regression coefficient of hatching time on holding time was 0.25 hatching period (about one hour) per day of holding. The correlation between egg weight and hatching time was not significant. cients.

It was noticed also that incubation period was increased by increasing inbreeding coeff-

\section{INTRODUCTION}

Several factors, both genetical and environmental, have been proved to affect the required hatching time of the chick embryo (BoHREN et al., I96I). Consistent differences in hatching time, as observed among breeds and lines of chickens, supported the heritable nature of this trait. (MORGAN and KoHLMEYER, I957 ; HASSAN and NoRDSKOG, I967; and ICHINOE, I973).

Several investigators reported that large eggs require a longer incubation time than smaller ones (WILIIAMs et al., I95I ; BOHREN et al., I96I; HASSAN and NORDSKOG, I967), however, ICHINOE (I973) reported that larger eggs tended to hatch earlier than smaller ones in the R.I.R. male R.I.W. female hybrid and vice versa in the case of the Shaver strain of W.L. HASSAN and NoRDSkog (1967) suggested that selection for high body weight retarded hatching time more than could be accoun- 
ted for by the correlated response in egg size and thus hatching time may have a genetic basis independent of egg size. Storage period of hatching eggs was also reported to affect hatching time. BOHREN et al. (I96I) and ZAWALSKY (I962) observed that increased preincubation storage time delayed hatching time. MoRGAN and KOHLMEYER (r957) reported that the expected " hatch-day " range was frequently more variable within inbred lines than that for the non-inbred purebred and that for crosses.

The aim of this experiment therefore, was to estimate the heritability coefficients of hatching time of Fayoumi chickens. Egg weight and pre-incubation storage were also investigated in relation to hatching time.

\section{MATERIALS AND METHODS}

Individual sire matings of Fayoumi males with females were used for heritability estimates of hatching time (length of incubation period). Twelve sires and 144 dams were randomly mated in family pens supplied with trap nests where each family was composed of one sire and twelve females. The pedigree eggs were collected for a period of ten days and the fresh egg weights were recorded daily.

The temperature of holding room ranged from $55^{\circ}$ to $60^{\circ} \mathrm{F}$. and all eggs were turned daily until six hours before setting. The eggs were incubated in forced draft machine automatically maintained at a temperature of $100^{\circ} \mathrm{F}$. and wet bulb thermometer reading of $86^{\circ} \mathrm{F}$. At the beginning of the 2Ist day of incubation the hatcher was opened every four hours to remove the hatched chicks which were completely free of their shells. The first four hours were assigned period number one and the removal of chicks continued through 12 periods ( 48 hours).

For statistical analysis, the dams used in this experiment had at least 3 offspring per dam, while the sires used had at least 4 dams per sire. Analysis of variance was based on the model given by KING and HENDERSON (I954), using an analysis appropriate to unequal subclass numbers. Variance components were for sire $(s)$, dam $(d)$ and full-sibs $(e)$. In a random mating population the variance arising from genetic differences between sire $\left(\sigma_{s}^{2}\right)$ is expected to contain one-fourth of the additive genetic variance, one-sixteenth of the additive $\mathrm{X}$ additive epistatic variance and a smaller portion of the higher order interaction variances involving only additive effects. The dam component of variance $\left(\sigma_{a}^{2}\right)$ is expected to contain one-fourth of the additive genetic variance, one-fourth of the dominance variance, three-sixteenth of the additive $\mathrm{X}$ additive epistatic, one-sixteenth of the dominance $\mathrm{X}$ dominance variance and a smaller fraction of the higher order interaction variances. Variance from maternal effects will also contribute to the dam component (LERNER, 1958).

Phenotypic correlations between egg weight and hatching time and between holding days and hatching time were estimated. The variables to be analyzed then were age of storage $\left(\mathrm{X}_{1}\right)$ in days, egg weight $\left(\mathrm{X}_{2}\right)$ in grams and hatching time $(\mathrm{Y})$ in periods.

In order to observe the effect of inbreeding on hatching time, eggs were collected from different inbred lines of Fayoumi hens having the coefficients of $6.25,12.5,25.0,37.5$ and 50.0 p. 100 plus a control of outbred hens.

\section{RESULTS AND DISCUSSION}

Table I shows that the distribution of hatching time approached normality with a mean of $2 \mathrm{I}$ days plus I.28 hours. Similar results were reported by BoHREN et al. (I96I) with a longer mean hatching time by about 1.72 hours in W. Leghorns. This may be due to the small size of local Fayoumi eggs (42.83 grams in the present experiment). 
Heritability estimates of hatching time were $h_{d}^{2}=0.28, h_{s}^{2}=0.08$ and $h_{d+s}^{2}=0.18$. It was clear that higher dam than sire component estimates of heritability for hatching time were observed. With the statistical model employed and random mating being assumed, variance arising from non-additive genetic and maternal effects may be expected to be found in the dam component of variance.

TABLE I

Distribution of hatching chicks during the different periods

Distribution des poussins éclos durant les différentes périodes

\begin{tabular}{c|c|c}
\hline \hline Periods & $\begin{array}{c}\text { Number of } \\
\text { hatching chicks }\end{array}$ & $\begin{array}{c}\text { Percentage total } \\
\text { number of } \\
\text { hatching chicks }\end{array}$ \\
\hline 1 & 186 & 13.0 \\
2 & 271 & 19.0 \\
3 & 194 & 13.6 \\
4 & 305 & 21.4 \\
5 & 188 & 13.2 \\
6 & 131 & 9.2 \\
7 & 91 & 6.1 \\
8 & 40 & 2.8 \\
9 & 12 & 0.8 \\
10 & 6 & 0.4 \\
11 & 2 & 0.14 \\
12 & 1 & 0.07 \\
\hline ToraL & 1427 & 10000 \\
\hline
\end{tabular}

Moreover, the correlation between the age of storage and hatching time was highly significant (0.37). The coefficient for the regression of hatching time on holding time (days) was 0.25 hatching period (one hour) $\pm 0.03, d . f=563$, $\mathbf{P}<0.001$. Similar results were reported by BoHREN et al. (I96I).

The correlation between egg weight and hatching time was not significant $\left(r=0.05\right.$ and $\left.b_{y x_{2}}=0.024\right)$. BOHREN et al. (I96I) reported a small and not significant correlation between these two variables on individual basis while it was significant between dam means. It had been shown by WILLIAMs et al. (I95I) that larger eggs required a longer incubation time than smaller ones. On the contrary, ICHINOE (I973) found that larger eggs tended to hatch earlier as mentioned in the introduction. The relationship between egg weight and hatching time in this experiment, is not clear $(r=0.05)$ and this may be due to the medium size of Fayoumi eggs. ICHINOE (I973) reported that eggs of medium size showed less difference in hatching time.

The following multiple regression equation was set up in order to predict the hatching time $(\widehat{Y})$, in periods, expected from a given egg weight $\left(\mathbf{X}_{1}\right)$, in grams, and holding days $\left(\mathrm{X}_{2}\right)$ :

$$
\widehat{\mathrm{Y}}=0.45 \mathrm{X}_{1}-\mathrm{I.04} \mathrm{X}_{2}+38 . \mathrm{I} 9
$$




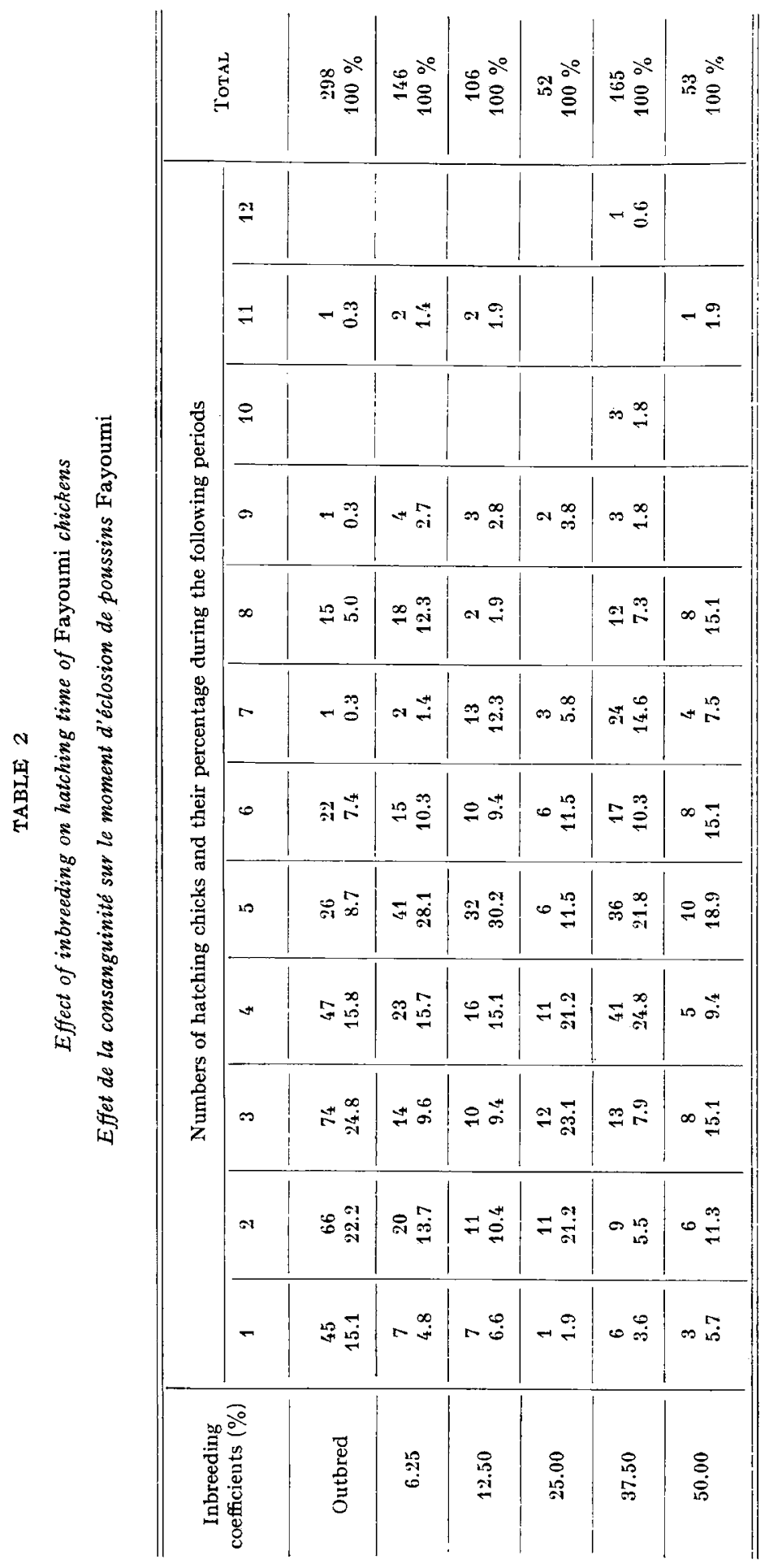


The effect of inbreeding on hatching time is shown in table 2. It was noticed that incubation period was increased by the increase of inbreeding coefficients. While most of the chicks (at least $50 \mathrm{p}$. 100) of the control group hatched during the first three periods, most of the inbred chicks hatched during the first five periods. Similar results were obtained by MORGAN and KOHLMEYER (I957). This may be due to slow growth rate of the embryos of inbred chickens.

Rę̧u pour publication en décembre 1975.

\section{RÉSUMÉ \\ ESTIMATIONS DE L'HÉRITABILITÉ DE LA DURÉE D'ÉCLOSION CHEZ LA POULE FAYOUMI}

Des œufs pedigree de la race Fayoumi fécondés par différents pères ont été collectés en vue d'estimations d'héritabilité de la durée d'incubation. Ces œufs étaient conservés pendant une période maximum de ıo jours avant la mise en incubation. Il a été observé que la distribution de la durée d'incubation était proche de la normalité, avec une valeur moyenne de $2 \mathrm{I}$ jours plus $\mathrm{r}, 28$ heures. Les estimations de l'héritabilité de cette durée étaient $h_{d}^{2}=0,28, h_{s}^{2}=0,08$ et $h_{a+8}^{2}=0,18$. La corrélation entre la durée de conservation des oufs avant incubation et la durée d'incubation était hautement significative $(0,37)$. Le coefficient de régression de la durée d'incubation sur la durée de conservation était 0,25 " période d'éclosion " (environ $\mathrm{I} h$ ) par jour de conservation. La corrélation entre le poids des œufs et la durée d'incubation n'était pas significative.

Il a été observé également que la durée d'incubation augmentait avec le coefficient de consanguinité.

\section{REFERENCES}

Bohren B. B., Crittenden L. B., King R. T., I96r. Hatching time and hatchability in the fowl. Poultry Sci., 40, 620-633.

Hassan G. M., Nordskog A. W., r967. Influence of selection for body weight and egg weight on embryonic growth rate and hatching time. Poultry Sci., 46, I27I.

Ichinoe K., r973. The relationship between hatching time and sex ratio in chicks. Poultry Sci., 52, I 584-I592.

King S. C., Henderson C. R., I954. Variance components analysis in heritability studies. Poultry Sci., 38, $147-154$.

Lerner I. M., 1958. The genetic basis of selection. New York, N. Y., John Wiley and Sons, Inc.

Morgan W. C., Kohlmeyer. W., I957 Relative worth of inbred chicks hatched from extended incubation periods. Poultry Sci., 36, II43.

IVIlliams C., Godfrey G. F., Thompson R. B., r95r. The effect of rapidity of hatching on growth, egg production, mortality and sex ratios in the domestic fowl. Poultry Sci., 30, 599-606.

ZAWALSKY M., 1962. The effect of sex, egg weight and preincubation storage on hatching time and chick weight. Poultry Sci., 41, 1697. 